\title{
The Way of the Firang: Illustrating European Social Life and Customs in Mughal Miniatures (1580 CE -1628 CE)
}

\author{
Soujit Das ${ }^{1} \&$ Ila Gupta ${ }^{2}$ \\ ${ }^{1}$ Assistant Professor of History of Art, Government College of Art and Craft Calcutta, West \\ Bengal, India. \\ ${ }^{2}$ Retired Senior Professor, Department of Architecture and Planning E Joint Faculty, \\ Department of Humanities and Social Sciences, Indian Institute of Technology Roorkee, \\ Uttarakhand, India.
}

\begin{abstract}
During the sixteenth century, along with the rise of the Mughal Empire, the social landscape of India changed drastically with the advent of the European colonial powers. In $158 \mathrm{o} \mathrm{CE}$, following the First Jesuit Mission to the Court of Emperor Akbar, a new cross-cultural dialogue was initiated that not only impacted the socio-economic and political fabric but also the artistic productions of the time. The growing presence of the European traders, ambassadors, soldiers, and missionaries in the Mughal world also lead to several curious narratives that were widely circulated. These tales also gave birth to cultural misconceptions as the Europeans on several occasions were seen as social evils. They were often collectively addressed as Firang/Farang or 'Franks' and were perceived as 'strange and wonderful people' or 'ajaib-o-ghara'ib'. It was during the Mughal reign when for the first time in Indian visual culture, a conscious attempt was made to document the life and customs of the European people. This paper attempts to understand how the processes of cultural alienation and Occidentalism had influenced the representation of Europeans in Mughal miniatures. It also argues how Mughal artists innovate new iconographic schemes to represent and perpetuate a sense of the 'other'. How artists used these identity markers to establish notions of morality as well as of Islamic cultural superiority. The select illustrations also attempt to elucidate how these representations of Europeans were culturally appropriated and contributed to the Mughal 'fantasy excursions'.
\end{abstract}

Keywords: Firang, Mughal, miniatures, Occidentalism, cross-cultural encounters

\section{Introduction}

The history of migration and settlement is entangled with each other. Cross-cultural conflict has its own unique character and political agenda of territorial expansion is of much importance. It is in the natural process of our cultural behavior that someone or something which challenges our notions of familiarity is readily suspected or contested. The Mughals also came to India as Timurids and in many places, their concept of design, warfare, and political systems reflected this association with these roots (Golombek \& Koch, 2017). The cross-cultural dialogues in Mughal India were no exception. The arrival of Portuguese or for that matter other Europeans was not entirely a new phenomenon. Europeans were present in India much before the Mughal power came into existence. ${ }^{\mathrm{i}}$ Before Vasco da Gama's arrival, six Venetians were located around north India in $1338 \mathrm{CE}$, following the overland route of Marco polo (Pearson \& Johnson, 1987). The

(c) AesthetixMS 2020. This Open Access article is published under a Creative Commons Attribution Non-Commercial 4.o International License (http://creativecommons.org/licenses/by-nc/4.o/), which permits non-commercial re-use, distribution, and reproduction in any medium, provided the original work is properly cited. For citation use the DOI. For commercial re-use, please contact editor@rupkatha.com. 
collapse of the 'Pax Mongolica' route in the mid-fourteenth century made such appearances much rarer. ${ }^{\text {ii }}$ Probably the number was too trivial to create a mass impact. Vasco da Gama or Alfonso Albuquerque indeed played a pivotal role in establishing a European stronghold along the Indian coastline, but they failed to venture deeper into the land. The early European invaders and settlers were at least clear in their motive as they were seeking 'spices and Christians' here (Pearson \& Johnson, 1987). In fact, the four main motives behind their overland explorations were (i) to launch a Crusade against Muslims, (ii) the desire to procure gold (iii) to search the legendary figure Prester John (iv) and to trade in Oriental spices (Graham, 2019; Guenther, 2015). In the name of God, they were serving themselves and this was only the inception for other western powers to occupy. ${ }^{\text {iii }}$ The appearance of the Portuguese must have been very exotic for the natives. Probably their external appearance or behaviors generated much curiosity among them.

In one such early confrontation, it is said to be recorded that the natives of some coastal town went to their king and described the Europeans as: "a race of very white and beautiful people, who wear boots and hats of iron and never stop in any place. They eat a sort of white stone and drink blood" (Cipolla, 1970). Europeans in general have been envisioned as strange and wonderful (ajaib-o-ghara'ib) people. Tahir Muhammad, the courtier of Akbar who was sent to Goa, praises and criticizes their habits at the same time. His account informs one that they wear very fine clothes but were very untidy and pimply in nature. He also informs that washing after relieving is considered improper in their community and that they take bath very rarely. Muhammad also praises them as good firearm users and brave sailors and sea soldiers. This idea about the Europeans or Franks finds reverberance in Shahjahan's memoirs. Shahjahan too admits them to be great people but despises them at the same time for their three main habits. Firstly they are seen as infidels or Kafirs, secondly for they are pork eaters and thirdly for their untidiness especially their untidy manners of toilet hygiene (Subrahmanyam, 2005). ${ }^{\text {iv }}$ There are also tales about the Frankish lands that were very popular. The imaginations ran wild within the Persian stories representing the Europeans and European lands in a realm of fantasy. Their lands appeared to be more exotic than reality and found parallels in the story of Arabian Nights. ${ }^{\mathrm{v}}$ Abu'l Faz'l himself believed that Europeans inhabited Jazair-i-Firang or Island of Franks, which they thought were in the ambit of possible capture but was not sure of its location (Digby, 1999). These stories were also told exclusively to Jahangir by an Iraqi raconteur. The notions about the westerner or Firang ${ }^{v i}$ aka Franks were thus conceived in several ways which were reflected through the paintings.

It is regardless to mention that the propagation of new religious order had little scope of prosperity under Islam. In the process of gaining a foothold, the early Portuguese inflicted their wrath on some Hindu domains by demolishing temples and imposing their own laws of worship (Axelrod \& Fuerch, 1996). But gradually this aggression was countered by the arrival of other European forces who proposed amicable policies of trade and rule. Most of these western powers were constantly in conflict with each other. They had their internal conflicts over acquiring the trade monopoly and also over religious affiliations of Catholicism and Protestantism (Panikkar, 1953; Subrahmanyam, 2017).

\section{Representing the Jesuits : A Visual Trope}

In 1580 A.D. reached the first European mission to Fatehpur Sikri and with them arrived many ideas of a new religion called Christianity. ${ }^{\text {vii }}$ It is to be remembered that this team of Portuguese delegates consisted of religious men who were seeking an opportunity for propagation. ${ }^{\text {vii }}$ Akbar's tolerance gave them enough opportunity to express and expand (Bailey, 2001; Kuczkiewicz-Fras, 2011). The first Jesuit mission gifted Akbar a sumptuous set of Plantin's Royal Polyglot Bible and 
images of Christ and the Virgin. ${ }^{\text {ix }}$ This inception ensured a steady flow of printed European books, etchings, and other souvenirs to the court. The next missions officially strengthened the relation and paved new ways of exchange. The random copies made in the Mughal atelier can be inspected at different lights. The early images were mostly copied from the Northern European sources ${ }^{\mathrm{x}}$ at the court and later the same sources along with the copies became a reference point for indigenous practice (Rice, 2009, 2017).

The Jesuit missions as well as later Franciscan missions, although failed in their attempt to convert the Mughal Emperor but have been eventually successful in gaining preaching rights and to convert few royals (Bailey, 1998; Camps, 2000; Maclagan, 1932). The Jesuits were even appointed to teach the young princes at the Mughal court (Moin, 2014). The Jesuit expectation of royal access has been negotiated through several dialogues which help one to understand the cross-cultural encounters. The royal meetings that the Jesuits held from the late sixteenth century mostly failed due to the mismatch between their predictions and reality. The Jesuits contributed to the advancement of Mughal art and culture in various ways, especially through collaborative works of translating both secular and religious western texts (Truschke, 2016). The tradition of translating Sanskrit text was prevalent in the Mughal court, but it was the Jesuits who kindled the interest in Western philosophy and other European texts (Lefèvre, 2012). The Jesuits were also often consulted by the Emperor and the artists who learned the iconographical traits of Christian figures. Father Jerome Xavier one of the most important Jesuits at the Mughal court, even mentions how Jahangir use to instruct his painters to strictly follow the colours of the European costumes (Das, 1978). It is interesting to note, that although Jesuits as a Europeans were widely recognized, their representations in Mughal paintings are limited as compared to other European subjects. The reason could be manifold. The atrocities of the Jesuits in the coastal settlement areas were well known where forced conversions were happening from early sixteenth century, especially during the Portuguese inquisition (Marcocci, 2014). The Jesuits were also famous for their religious book burning activities. Thomas Coryat's account informs one that Portuguese Jesuits even insulted the Muslim sentiments by tying a Quran to a donkey's neck and parading it around the city. However he also notes that Akbar's mother also insisted Akbar to humiliate the Christians by doing the same with the bible, but he refused commit to the act (Razvi, 2012). The Mughal emperors had shown much liberal side while dealing with the Jesuits. The Jesuits appeared very exotic with their unusual robes, hats, rosaries, and holy book. This standard means of identifying them were also taken up into paintings as an individual painted figure, detailing out their dress and appearance. They were repeatedly painted within these similar schemata either in group compositions or as a single figure. ${ }^{\mathrm{xi}}$ The Jesuits with their first appearance at the court turned many heads with their outlandish attires. They came to be known as siyaahposh or blackrobed as many of them wore that colour. The Mughal courtiers also nicknamed them as 'black devils' (Okada, 2004). In contrast to their nickname, in most Mughal paintings, the Jesuits appear wearing blue coloured robes, a colour held in high prestige within Christian symbolism. The relationship of Mughal Emperors with the Christian religious preachers has always been ambivalent. Jesuits who visited the court of Akbar and Jahangir has always been active in establishing the religious superiority of their doctrine. On the contrary, Muslim religious men too denigrated Christianity. The Majalis-i-Jahangiri of Abdus Sattar records several such cases, where debates between two learned groups, often took an ugly turn, especially when the Muslims attacked the intension and the faith of the Jesuits. ${ }^{\text {xii }}$ 


\section{Identifying the Ethnic Peculiarity of the Firangs'}

The early modern European urban settlement was predominantly 'surrounded by a larger population of Indians (and other Asians), whether merchants, weavers, spinners, dyers and cloth painters, other artisans, labourers or agriculturists' (Subrahmanyam, 2018). The Europeans became a community which not only intrigued the Mughal populace but their social customs too generated much curiosity amidst the artists. Much information about European social life in the imperial Mughal world is derived from the miniatures. The Mughal miniatures depicting Europeans is a curious mix of observed reality, imagination, and projections. In the Mughal world, the identity of French, Portuguese, Spanish, English, and other Europeans came under a homogeneous understanding: they were collectively seen as white-skinned foreigners. The European ethnic identities merged as one for the Mughal people. Genre scenes became very popular in Mughal atelier and scenes of European life started to surface.

The presence of the white-skinned Europeans in Mughal imageries and the intension behind such depictions can all provide insights to the representations and perpetuations of otherness in Mughal India. The Europeans especially the Portuguese gained notoriety for their actions and were perceived as social threats. ${ }^{\text {xii }}$ These issues are particularly important in this context, given that for nearly two centuries of Mughal rule a certain homogeneous/standardized representational formulae had been invented. The frequent portrayal of non-Indian races definitely prefigured or showed signs of internalization as well as internationalization. It can be presumed that the Mughal patron being aware of the western powers by that time, wanted to acknowledge the ethnic oddities of Europeans in order to be consistent with its own superior image. The European in general especially Portuguese for their frequent appearances from the late $16^{\text {th }}$ century had taken the fancy of the artists.

Over their long residence in India the Portuguese have adapted their dress to the demands of the climate, retaining their usual cloaks and doublets (though the materials would have been lighter in the hot season), but replacing tight knee-breeches and hose with loose trousers gathered in at the ankle for coolness and protection against mosquitoes (Crowther, 1960). Such costumes were often depicted in Mughal paintings from 1590 CE. (Rogers, 1993). ${ }^{\text {xiv }}$ The unfamiliar fashion probably lured the artists to depict exotic foreigners (Markel, 2015). Indian loose clothing had been developed over several thousand years to suit its topographical and climatic conditions. These European garments were definitely a misfit. The European journals also mention that when Europeans first arrived in India, the road was crowded with anxious people, while the children and women followed them with great curiosity (Beach, 2004).

The Portuguese in Mughal India came to be known as the Kulah-posan or Hat wearers (Natif, 2018). The Europeans in general too were identified by their unusual costumes. The Jesuits could be identified by the distinct hats worn by them. The popular galero or broad-brimmed hat with tessellated string appears many times in Mughal paintings along with Prelet hat, Kamikhavka hat, Tudor's bonnet hat, Ausge hat, Spanish toque hat, and Pileurs cap amongst others. The Jesuit hats are devoid of feathers as they were a mark of aristocracy and military achievement. The Kingly figures could be identified by distinct multi-pointed armour crowns and the crown jewels. The noblemen are seen wearing different types of felt, cloth, silk and velvet Beret, Beaver, and Bonnet hats decorated with different types of feathers and jewellery, a fashion prevalent in Renaissance Europe. The soldiers could be easily identified by their helmets especially the Spanish archer's helmet, Morion, Sallet, Burgonett, and Cabasset amongst others. They also wear different Cuirass or armour. Women often wore laced ankled boots with fur lining. Men could be seen wearing 
breeches, hose, and chausses as a distinct European garment. The wealthy of the sixteenth and seventeenth-century Europe also wore the ruff collars. Amongst the shoes buckled low boots, banded combat boots, Attila boots, half-boots and ankle shoes, poulaines, etc. could be spotted in the miniatures.
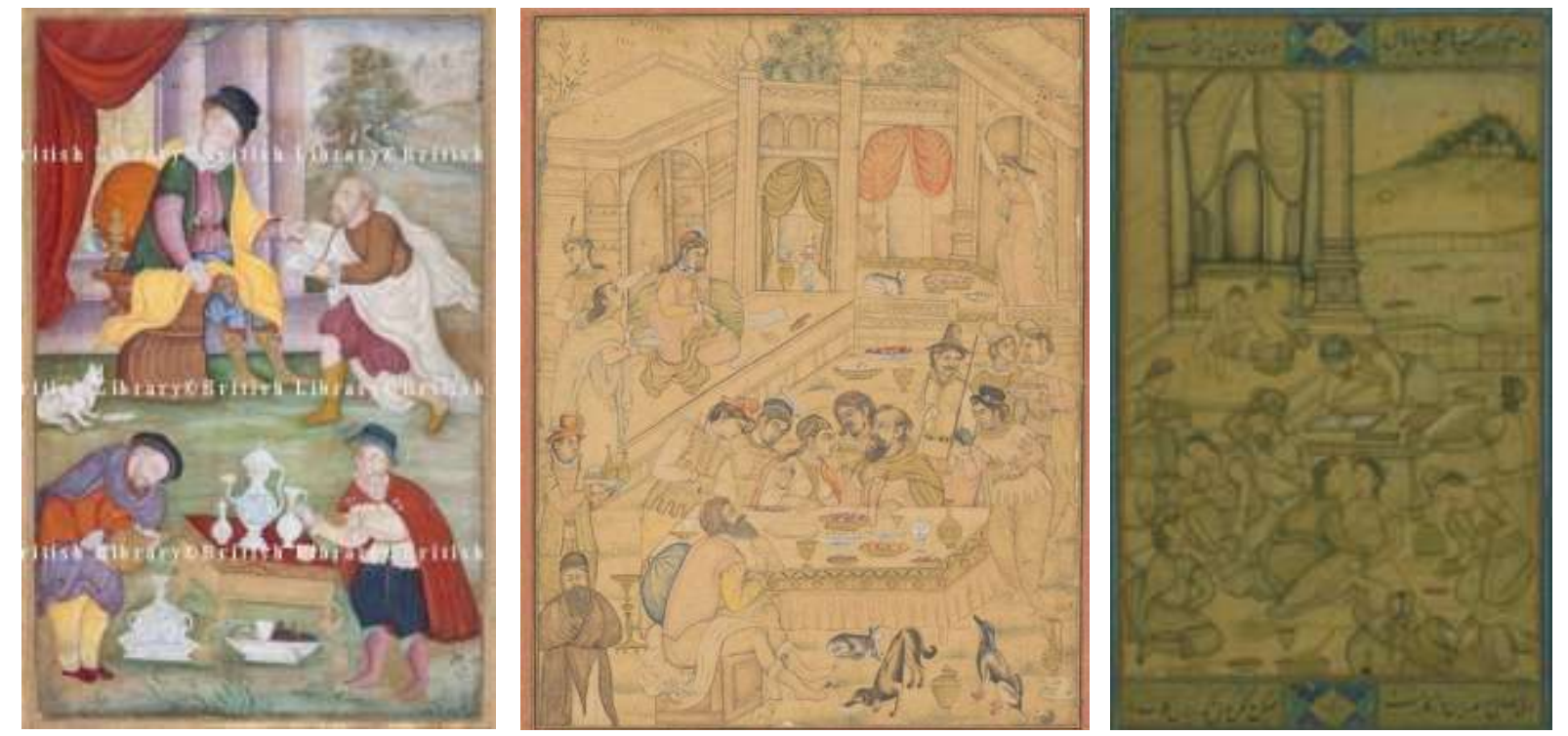

(1) Fig. no. 1: A European Scene with Portuguese Figures by Sanvala, 160o CE. British Library London. Museum no: 010696

(m) Fig. no. 2: European Banquet Scene, 1595-160o CE, Art Institute of Chicago. Reference no: 1919.891 (r) Fig. no. 3: Party of Carousing Europeans, 1605 A.D. Victoria and Albert Museum London, Museum no: D.399-1885

In Fig. no. 1, which represents a European genre scene, one comes across a European gentleman sitting on a savaranola chair, reading a book held by another figure. In the foreground one find two attendants preparing for coffee, as the elaborate arrangement suggests. The dining and feast scenes were very popular amongst the Mughal painters and this format was borrowed from European sources into the Mughal composition. It has been observed in recent scholarship that the script visible in the book is of 'pseudo-European character'. On a closer look, the vessels on the ground reveal European designs. Losty and Roy notes that the figural scheme has not been entirely copied from an European engraving, rather it is an unique composition in its own merit, probably modeled after real life observations (Losty \& Roy, 2012). In Fig. no. 2, the European banquet scene depicts European men and women at the same place, enjoying the sumptuous meal. The emphasis is given to the ambiance, where the dogs are seen loitering in the search of food ${ }^{\mathrm{xv}}$ Here with light colour washes the painter brings the scene to life. The artist here does not miss to portray the different headgears, hairstyles and moustache/beard styles that were popular amongst the contemporary Europeans. Amongst many objects that appear scattered in the painting, the wine cups and the attendant with wine bottles is hard to ignore. The painter provides a glimpse of the inner world of a European house. In Fig no. 3, several carousing Europeans are painted, easily recognized by their distinct attires. At the centre two European couples are shown in romantic embrace while other figures appear drunk and enjoying the feast. Two naked children figures could be seen in the distance, seated and playing with a barrel like object. Interestingly two male European figures at the centre are shown inspecting painted 
manuscripts. The Mughal artists repeatedly introduced the theme of drinking especially in the European genre scenes. It should be noted that drinking parties were not amongst the commonest of subjects painted by the Mughal artists during the late $16^{\text {th }}$ and early $17^{\text {th }}$ century. It became a popular theme at a later date. Although alcohol consumption was common in the Mughal world but they were also a taboo due to the Islamic religious proscription. Scholars have noted that from the early days of European settlement especially that of EIC, high level of alcohol consumption has been a major problem in all segments of Anglo-European society. There are even mentions of several well documented inventories which took note of the wide range of brew, which was imported in Mughal India. In fact, alcohol consumption after two main meals of the day was in the cultural habit of all Europeans (Fischer-Tiné, 2012). The Mughal artists must have taken note of such habits and incorporated the same while imagining the Europeans as 'others'. ${ }^{\text {xvi }}$
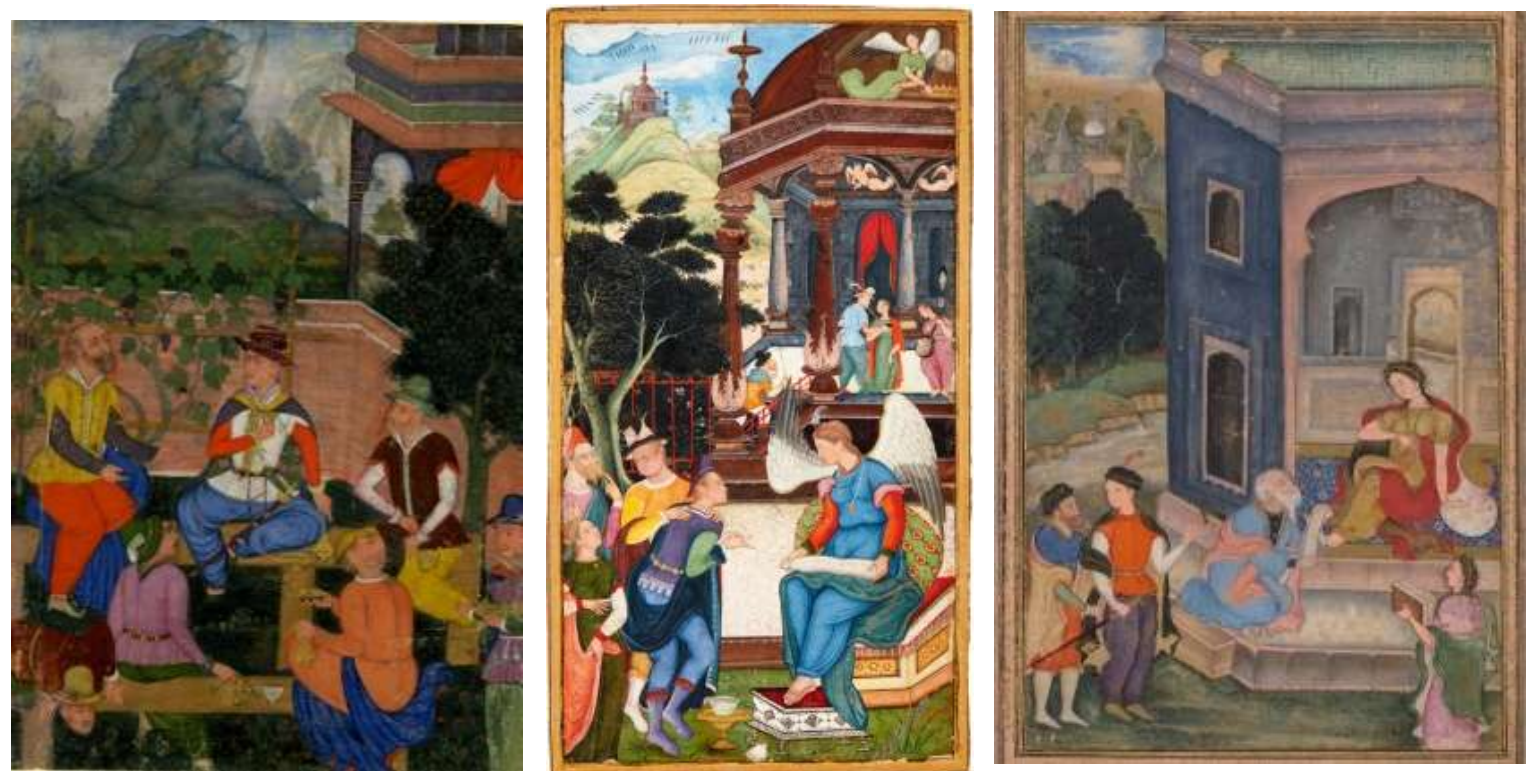

(1) Fig. no. 4: Recreational scene of European men drinking , 1625-1650 CE, British Museum, Museum no: 1974,0617,0.3.9

(m) Fig. no. 5: Angel conversing with a group of Europeans, 1610 CE, David Museum Denmark, Inventory no: $06 / 2013$

(r) Fig. no. 6: European Costume Scene, 1590-1595 CE, Cleveland Museum of Art, Museum no: 1971.89

The next image (Fig. no. 4) shows a recreational scene of 'Europeans drinking within a walled garden'. The jolly company of men engages in a friendly discussion seated with much ease within the walled premise. The interior of the European household is often painted with improvisations, giving the whole act a certain homely atmosphere, though the sense of otherness is strongly retained. The genre scenes often repeat the same compositional tropes. It reuses the elements of European architecture as a corner backdrop, introduces folded red curtains; places the protagonist or the important characters at the foreground against it, whereas other figures are shown paying a visit. The aesthetics of the built environment could not be overlooked in these works as they present facets of a distinct culture, albeit borrowed from European prints. The holy book, European clothing, and architectural settings all became vehicles to project the foreign characters. Here in the painting apart from giving attention to the European costumes and the drinking arrangements, the artist observes the scene very closely. At the left corner of the image, 
appears a European man, who seems like vomiting in the garden. To reiterate the theme, the artist also painted grapevines with grapes as a background of the figures. In Fig. no. 5 the female angel is shown conversing with a group of Europeans at the courtyard, wherein the distance another couple and a musician appear. The angel indirectly confirms to their affiliation with Christianity. Solomonic angels also appear over the dome, which were also allegorical symbols of just rule. ${ }^{\text {vvii }}$ One can hardly ignore the extremely pale palette used to paint the skin of the figures. This was one of the common method to provide validity to a European scene. For the Mughal painters every European appeared as followers of Christianity, thus elements of crucifix or holy bible were randomly painted as props. Here in the painting one can notice a European hatwearing gentleman just beyond the fence carrying a crucifix in his hand; although his dress does not confirm his association with any Christian religious order. The portrayal of the angels could be compared to that of Kinnaurs who appear in Indian texts but their portrayal became widespread through the trans-Himalayan trade (Singh, 1992). ${ }^{\text {xiii }}$ Fig. no. 6 also uses the same compositional trope where the main figure is probably borrowed from a European print. Here the architectural setting mimics a contemporary Mughal edifice. The stooping figure of the old man, reminds one of annunciation scenes but on a closer look it appears to be a secular scene. The two visitors in contemporary European dress, the man with an open scroll as well as the attendant with a book in her hand reaffirms the claim. Interestingly one can notice that in each composition, lush landscapes were painted in the backdrop. Natif suggests that they served an allegorical purpose representing agricultural productions, new land regulations, balanced revenue and taxes and political stability. It promoted the goals of sulh-i-kull or peace with all and also confirms the success of the just ruler who followed the Akhlaqi model and Sharia law (Natif, 2018). Thus Mughal artists embedded several visual codes to reconfirm the Mughal ethos of tolerance.

\section{Visual Legitimization of the Prohibited: Case of Firang Couple Portraits}
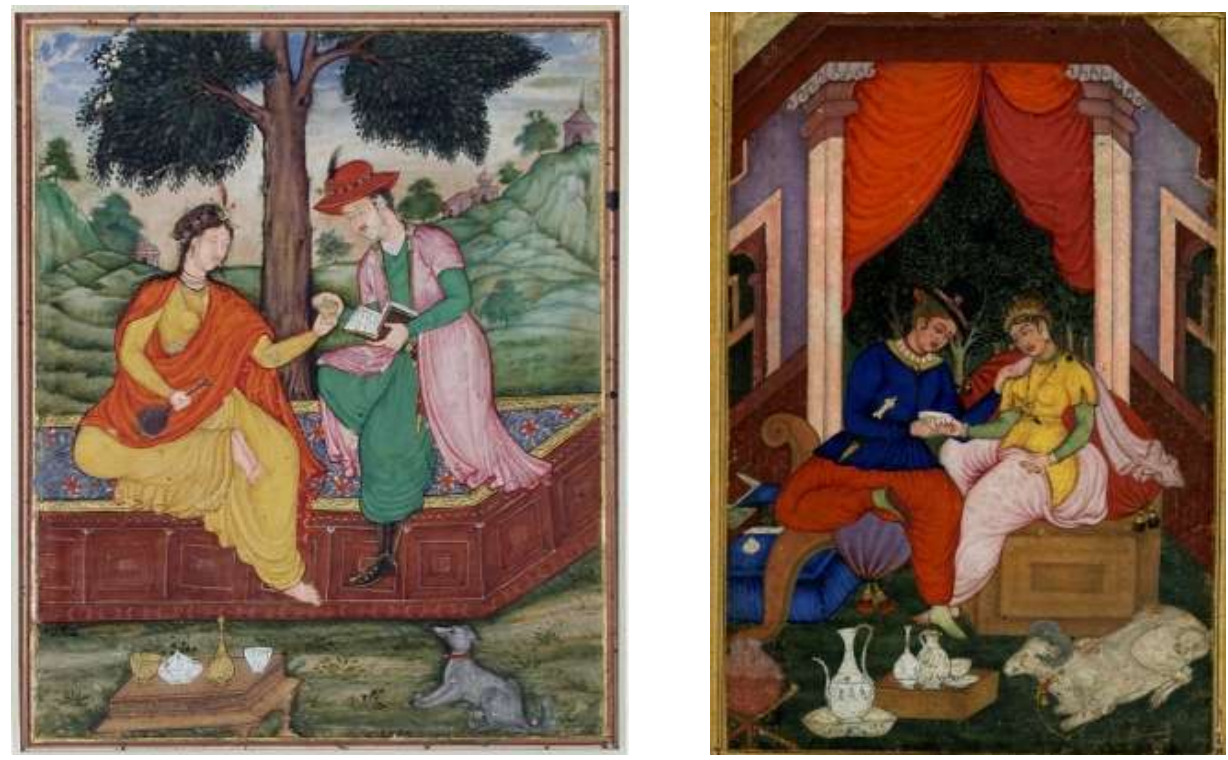

(1) Fig. no. 7: European Man and Woman sitting beneath a tree, 1590 CE, San Diego Museum of Art, Museum no: 1990.310

(r) Fig. no. 8: An European Couple, 1590 CE, British Museum, Museum no: 1920,0917,0.241

European couples too became a favourite subject for Mughal painters. Mughal painters refrained from depicting love scenes involving Indian characters at an early date. Even in the 
Safavid court of Isfahan European couple portraits showed similar tendencies of portrayal. It often represented amorous European erotic couples involved in all forms of indecency. Persian artists even painted such images in public murals (Babaie, 2009, 2013). These visual motifs were probably borrowed from the Persian court, as images and ideas in the early modern world traveled very easily. During the $15^{\text {th }}$ and $16^{\text {th }}$ centuries, the Mughal and Persian empires both witnessed the growth of the European Communities, and travelers and ambassadors often passed through both the lands. The Europeans also played a political role in redefining age-old connections (Brancaforte \& Brentjes, 2012). Mughals through their own political, cultural, and trade connections adopted many traits of their central Asian counterparts. ${ }^{x}$ Amy Landau has mentioned in her works how in the Persian world of $17^{\text {th }}$ century, European nudes were used to reflect local transformations of sexual attitudes. How their representations were eroticized and became an object of commentary and scrutiny posing questions about women's morality, decorum as well as ideas of prostitution (Landau, 2013).

In Fig. no. 7 a European couple shares a drink under a tree in an open landscape. The man wears a typical European red velvet hat and sports a red short moustache; a style popular with the European men. Ample arrangements for drinking could be seen on the ground, where a dog quietly observes the event. In Fig no. 8 similar actions of so-called immodest behavior come into play. The man and the woman dressed in proper European raiment, both appear in the cozy interior of an open room seated on a sofa. They were shown sharing a drink with each other where the man's left-hand touches the shoulder of the female in a tender and gentle way. Their legs appear entwined with each other engaging themselves in an amorous affair. ${ }^{\mathrm{xx}}$ Ample arrangements for drinking can be seen on the floor. The long necked wine flasks itself were markers of sexuality rather it emerged as sexual symbols in the Indo-Persian paintings (Langer, 2013). Such proximity between the sterner and the fairer sex was indeed rare in contemporary pictorial tradition. But still, it should be questioned how much such uninhibited depictions of love were approved during Mughal times. Another interesting issue which demands attention here is that in this picture it seems like the whole event is taking place in an inn. The identity of the woman concerned in the act is ambiguous. She could be a lover or even a mistress, which certainly raises the issue of ethics, etiquette, and morals. In both these figures (Fig no. 7 and Fig no. 8) an animal is represented near the feet, a trope used in several images dealing with European themes. Although these animal figures were randomly borrowed from European prints but they found new contexts in the Mughal world. Yael Rice suggests that from an early date these animal motifs were associated with personal attributes and cosmic identities (Rice, 2018).

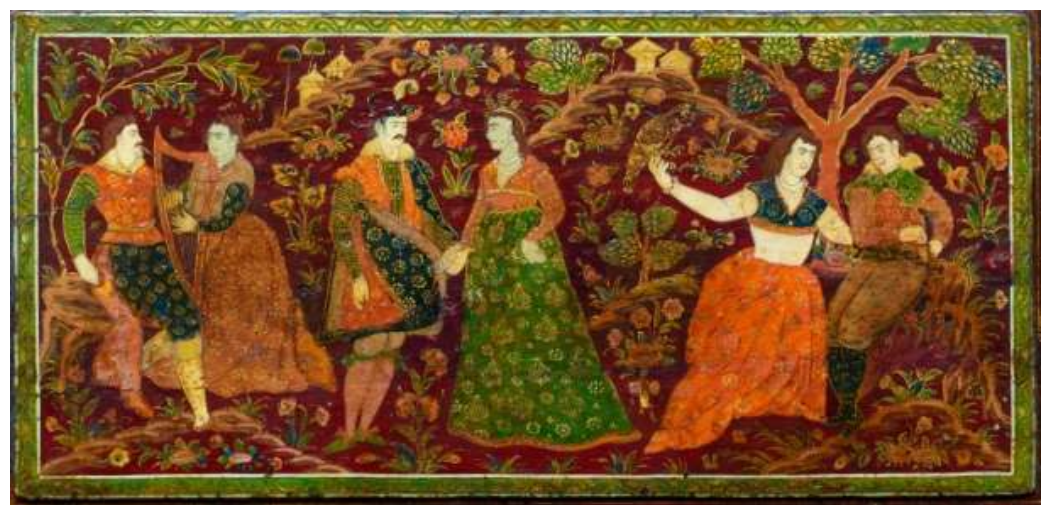

Fig. no. 9: Three European couple, painted wooden lacquer box, 1620 CE, David Museum Denmark, Inventory no: 29/2014 
Another unusual example (Fig. no. 9) is a wooden lacquer box decoration from Mughal Gujrat, where three prominent European couple appears on the top lid. The couples in their European attire were shown engaged in amorous acts and caressing each other within a garden in seclusion, as suggested by the distant architecture. The identities of these couples are ambiguous. The woman on the left plays a harp like instrument while the figure on the right holds an exotic bird, entertaining the other. The blooming flower garden adds to the romantic ambiance. Female figures in European clothing carrying different musical instruments became a favorite subject of the Mughal painters. The intension behind painting these figures was never clear. They were often placed against the stark background, as an isolated form. In many cases they are seen engaged in ambiguous acts. The widely popular allegorical female figures were mostly seen holding some or the other musical instruments.

\section{The Appropriation of the Rituals}
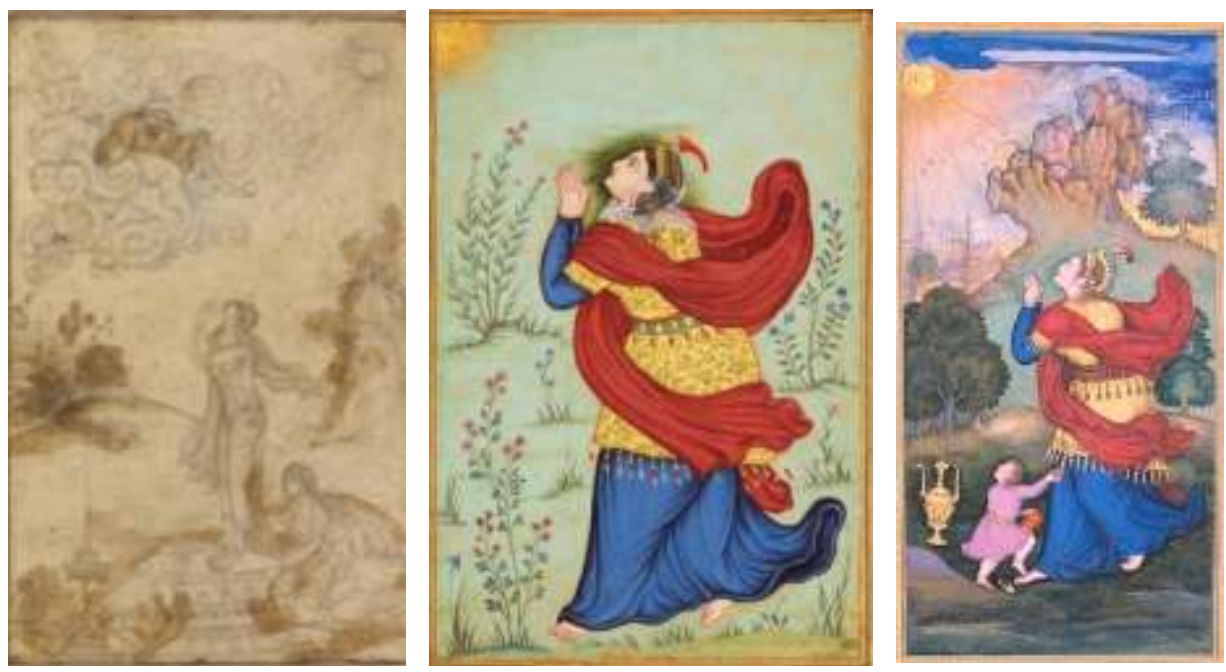

(1) Fig. no. 1o: Praying female figure, late $16^{\text {th }}$ century, Louvre Museum, Retrieved from art.rmngp.fr (m) Fig. no. 11: European Lady worshipping the Sun by Madhu, 1595 CE, Sotheby's London, Lot of $19^{\text {th }}$ October 2016

(r) Fig. no. 12: Woman worshipping the Sun, 1590-95 CE, Musee Guimet Paris, Retrieved from art.rmngp.fr

Fig. no. 10 provides a clue to the tendencies of appropriation where a praying female figure appears with her clasped hands looking up in the sky. The god-like character amidst the cloud appears here but his identity or the purpose remains obscure. In 'Woman worshipping the sun' (Fig. no. 11 and Fig. no. 12) both the figures appear in an Indian landscape with European dress but shown worshipping the sun. This religious practice was a dominant Hindu custom. Depiction of such kind, questions the intension of the artist. Whether these artists wanted to visually accommodate them within the Indian customs or it was just another experiment, remains unanswered. The uncanny similarity between the dress and the posture also brings forth the curious practice of copying at the Mughal workshop. Executed by two different hands, the colour scheme, drawing as well as the folds of the drapery complement each other. The upper garment shows motifs that have been borrowed from the Mughal designs seen in architecture, a trend that artists were often engaged with (Bhatnagar, 2009). Sun worship was also prevalent amongst the Zoroastrians who were also part of the Mughal populace. Whether the artists referred to such religious rituals is difficult to address. 

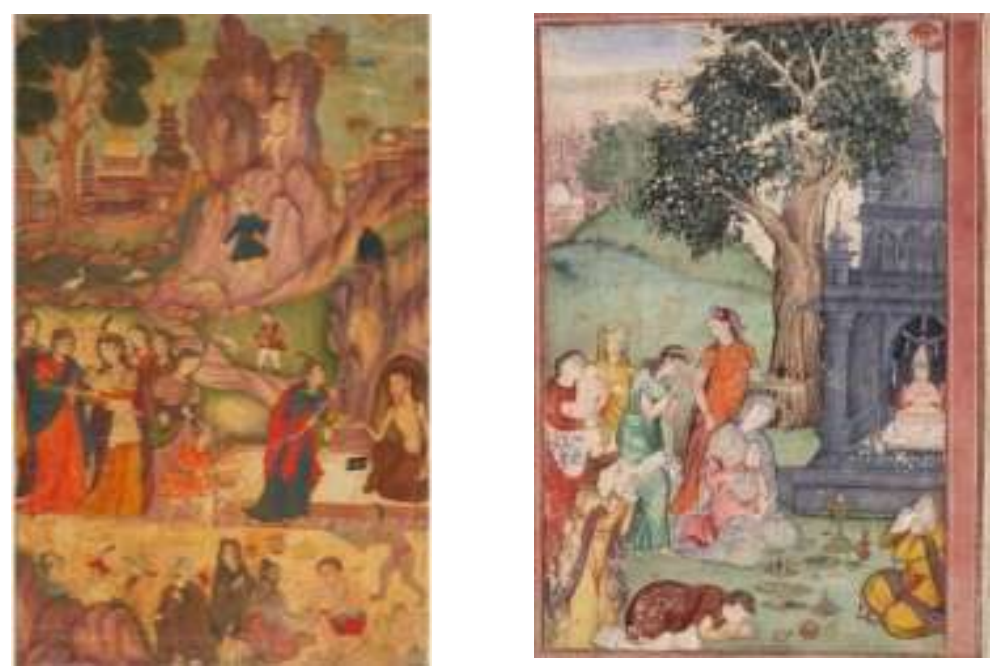

(1) Fig. no. 13: Noble Woman visiting a Yogi, 1595 CE, Sotheby's London, Lot of $20^{\text {th }}$ April 2016 (r) Fig. no. 14: Women worshipping at a Hindu Shrine, 1600 CE, British Museum. Museum no: 1954,1113,0.33

The process of appropriation gets much more prominent in Fig. no. 13 and Fig. no. 14. In the first image, several European women are shown on the outskirts of the city meeting a holy man at his retreat. Several Nath-yogis are also depicted in the foreground while few European men are shown lurking behind the trees and in the landscape. The most interesting section is the meeting of the two individuals where the artist had placed the same blue jacketed holy book near the sage. This entire composition was probably borrowed from a European original image depicting 'presentation to the temple' where the Mughal artists omitted as well as added many things. Fig. no. 5.97 internalizes the idea of appropriation by setting up a more convincing ambiance. The eight European female figures are shown venerating a Hindu god at a temple where a figure on the foreground could be even seen blowing the conch shell. On the extreme left side of the group appears a mother and child figure, much closer to the Madonna seen in Mughal paintings. The central figure of a blue-robed woman with clasped hands reminds of the nativity scenes. The blue robed women were often represented as Virgin Mary where the blue robe itself was an important Christian symbol. The figures here were probably borrowed from European engravings but the Mughal artists placed them in a new cultural context, generating new meanings. This could be read as an attempt of pictorial subjugation.

\section{Conclusion}

Europeans in Mughal India were given importance as a social group. Their growing presence not only kindled the curiosity of the natives and sovereigns but also established their major religion i.e. Christianity to a great extent. Their customs, habits, and rituals were not commonplace thus Akbar and his successor's wanted to document their presence in a more specific manner. In the process of painting from the European sources and from personal experiences in a physical space, the artists came up with schemes to easily identify their presence. Their outlandish fashion became an easy reference point from where artists repeatedly used them as tropes in the painting. The powerful Jesuits who were recognized widely by the court and the common folk became the scapegoat for visual experimentation. The same happened with other European figures and themes. In most cases, the attempt to isolate the characters and portray them in their physical exactness gives one a sense of the Mughal intension. Gradually their presence was internalized and their motifs and themes were appropriated, transforming the sacred into profane. European 
prints and objects had been constantly referred and they make their appearances in one or the other way. The European social groups with their own individual identities find mention in the visuals. The amorous couple figures or the drinking Europeans became a vehicle for experimentation. The acts which were otherwise prohibited in the Mughal world were taken up as themes, where European figures were painted. This was an act of subjugation as well as appropriation. In this way several ideas of Occidentalism gets reflected in the works. The ideas of Mughal cultural supremacy were also established in the process, as the Firang were not only despised but they were constantly perceived as inferior, evil and treacherous infidels. Female nudity of native woman is quiet rare in the early Mughal genre up to the mid $17^{\text {th }}$ century. The courtly scenes or harem scenes do show women in conversation or engaged in other activity but they assume the roles of mother, lover, attendant, or woman of historic importance. With the arrival of European prints and images- the image of the female nude was circulated in abundance. The western and the Indian/Mughal conception of the nude body were essentially not the same. The former often champions it as a natural state of being depicting the beauty of the human form. The idea of purity and feminine was also attached to it, whereas the latter commonly denotes the notion of shame and amorality with it. Thus it could be said that the European female figures became a vehicle to allegorically project indecent and amoral acts in Mughal India. The Mughal artists engaged in a process which could be dubbed as 'fantasy excursions' in Millie R. Creighton's words.

\section{Notes}

\footnotetext{
${ }^{\mathrm{i}}$ Muslim world at large has always been in contact with the Europeans during the Early Modern Period. It is to be noted that Indo-Persian texts produced upto the late $17^{\text {th }}$ century do not elaborately discusses the life and customs of the Europeans. As Juan R. I. Cole notes that mentions about Europeans in these texts were mostly 'few and episodic' which does not provide a complete picture (Cole, 1992). Thus paintings produced during this era in the Indo-Persian world provide crucial information about the European presence.

ii During this time several strange narratives about India were in circulation in Europe. The fourteenth century influential work of Sir John Mandeville is one such example which influenced several voyagers of fifteenth century, including Christopher Columbus. See (Vanina, 2013).

iii Portuguese families from early $16^{\text {th }}$ century often procured royal grants for their family members, so that they could travel to newly discovered Asian lands and become a factor/captain/governor/ viceroy etc. India too was perceived as a land of opportunity and wealth (Subrahmanyam, 2019). Several others especially the Germans, Italians, Flemish and Dutch people arrived initially with the Portuguese armada to India. Many of them were part of the artillery of the Portuguese. See (Kalus, 2015; Salonia, 2019).

${ }^{\text {iv }}$ Hanafi juricist, Ahmad Sirhindi repeatedly criticized Europeans for their faith, addressing them as Kafir-i-Firang or Frankish unbelievers.

${ }^{v}$ Sanjay Subrahmanyam notes that the awareness about Europe suddenly took a leap in the $16^{\text {th }}$ century but its topographical location was still vague; it only emerged as an imagined land from where Franks or Kulah-poshans (hat-wearers) came. None of the early writers including Arabian chronicler Hadrami bothered to discuss about specifics of their origin (Subrahmanyam, 2005).

${ }^{\text {vi }}$ Firang is also addressed as Firangi as well as Farangi

${ }^{v i i}$ For detailed discussion see (Camps, 2000; Maclagan, 1932; O’Malley, Bailey, Harris, \& Kennedy, 2000).

viii Prior to their arrival at the Mughal court, the Jesuits had visited the court of Adilshahi Bijapur Sultan Ali Adil Shah around $1561 \mathrm{CE}$, where the delegation was harassed and ridiculed with a barrage of perplexing queries. They gifted the Sultan a velvet covered bible and a book by medieval aesthetician St. Thomas Aquinas (Alam \& Subrahmanyam, 2011).
} 
ix The Royal Polyglot Bible published by Christopher Plantin in Antwerp between 1568-1573 CE was also known as Biblia Sacra; the Biblia de Montano; the Plantin Polyglot and the Biblia Regia. The collaborators of this bible were Catholics, Kabbalists and Calvanists. For further details see (Brekka, 2012)

${ }^{x}$ The Polyglot Bible included works of major Northern European masters. Ebba Koch in her recent work has discussed in depth how Northern European works especially from Antwerp had influenced and affected the pictorial language of the Mughal miniatures. For further discussion see (Koch, 2019).

${ }^{x i}$ Compare the following images to understand the repeated scheme of representing robe and cap wearing, bible holding figures of Jesuits. Compare Image of Francis Henriquez and Rudolf Aquaviva of the first Jesuit mission in Ibadat-khana, painted by Narsingh in Akbarnama around 1600-03 CE (Chester Beatty Library Dublin, Object no: In03.263) with Father Jerome Xavier's representation by Abu'l Hasan in 1605 CE (Institute of Oriental Studies, Ms.E- ${ }_{14}$,fol.10); Manohar's and Abu'l Hasan's depiction of Father Francisco Corsi in Jahangirnama, painted around 1624 CE (Museum of Fine Arts Boston, Accession no:14.654); Image of Jesuit Missionary from late $16^{\text {th }}$ century sold at Christies on $10^{\text {th }}$ June 2015, Lot.12; Image of Jesuit Priest from late $16^{\text {th }}$ century in Walters Art Museum (Accession no:W695.A); Portrait of a Jesuit from 1590 C.E. at National Museum, New Delhi; and Image of Jesuit Priest painted by Kesu Das around 1595-1600 CE (Chester Beatty Library Dubin, Museum no: CAT.81). Christian priests in Mughal miniatures acquire the similar traits everywhere.

${ }^{x i i}$ Majalis-i-Jahangiri informs one about several incidents. Maulana Taqiya Shushtari for instance called Christianity a 'false doctrine'. He infact refuted the translated Christian works produced by Jerome Xavier. In fact Abdus Sattar who collaborated with Jerome Xavier in the translation projects, expressed his doubt about Christians and Christianity, addressing it as 'most false, most impure and dirtiest'. The same source informs that Jesuit Jose de Castro denigrated Islam during the debate. (Alam \& Subrahmanyam, 2009, 2011). Also see (Lefèvre, 2012).

xiii Shaikh Zain al-Din Ma'bari's work informs us about the atrocities committed by the Portuguese against the Muslims. The narratives about other atrocities committed against hindus also painted a vicious picture of the Europeans. As a whole Franks were despised by each known Persian or Arabic chroniclers who recognized their presence. At the same time they and everything related to them was viewed as exotic. Subrahmanyan states that Seventeenth century Sankrit texts such as Venkatadhvarin's Visvagunadarsacampu also records that these white faced are merciless people and paintsthem in negative light. Athough they address them as Huna. The infamy of Portuguese were spread across Asia, as several $16^{\text {th }}$ and $17^{\text {th }}$ century Chinese records accuses them as child eaters apart from being treacherous and evil (Subrahmanyam, 2012). This too made them a real social threat.

${ }^{\text {xiv }}$ Also see the famous portraits of Europeans (often mistaken as portrait of Henri IV of France/Charles V and Sir Thomas Roe) painted around 1610-15 CE and housed at Victoria and Albert Museum London (Museum no: IM.386-1914 \& IM.9-1913); Painting of embracing Europeans, executed around $1590 \mathrm{CE}$ and Portrait of Portuguese Man in the collection of Los Angeles County Museum of Art (Museum no: M.83.105.20 \& Museum no: AC1995.230.1)

${ }^{x v}$ Similar idea is implemented in another work (The Rich Man and Lazarus after Jan Sadeler's print of Jacopo Bassano's painting, painted in early $17^{\text {th }}$ century, sold at Sotheby's London. Lot of $9^{\text {th }}$ October 2013). Here a biblical scene transforms into a genre scene. The story of Lazarus and the rich man was depicted here but the spatial arrangement is altered in the process of copying from the European print. The image of feasting and frolic remains constant.

${ }^{\text {xvi }}$ Even in Hindu society, drinking wine or alcohol was seen as one of the four worst sins. Diogo do Cuoto, a $16^{\text {th }}$ century Portuguese chronicler also testifies this view in his own accounts as he is said to have engaged in conversations with learned Brahmins. Diogo do Cuoto's account also informs us about several incidents where he and his fellow Europeans were seen as 'un-touchables' for their ethnic habits. Brahmins behaved in a way as if they 'were ill from some disease contagion' (Henn, 2014).

${ }^{\text {xvii }}$ For further details See (Koch, 2010, 2015; Parodi, 2001)

${ }^{x v i i i}$ As the Kashmir area was under the Mughal dominion, one cannot rule out the possibility of the cultural influence of nearby Buddhist monasteries.

${ }^{\text {xix }}$ See (Edwards, 1915). 
${ }^{\mathrm{xx}}$ (Subrahmanyam, 2005) mentions accounts of Tahir Muhammad who notes that popular narratives of Portuguese men's sexual prowess also added to the growing curiousity. Tahir termed the European women as shameless (bighairat) who easily commits to a man's desire. Clearly such ideas of morality were transmitted easily within the Mughal world. Tahir Muhammad's account appear around 1579/1580 CE and provides an important clue to understand the exact kind of knowledge in circulation. It could be speculated that artists too were exposed to such popular narratives.

\section{References}

Alam, M., \& Subrahmanyam, S. (2009). Frank disputations Catholics and Muslims in the court of Jahangir (1608-11). Indian Economic \& Social History ..., 46(4), 457-511.

Alam, M., \& Subrahmanyam, S. (2011). Writing the Mughal world: Studies in Political Culture. New Delhi: Permanent Black.

Axelrod, P., \& Fuerch, M. A. (1996). Flight of the Deities: Hindu Resistance in Portuguese Goa. Modern Asian Studies, 30(2), 387-421. https://doi.org/10.1017/s0026749x00016516

Babaie, S. (2009). Visual vestiges of travel: Persian windows on European weaknesses. Journal of Early Modern History, 13(2-3), 105-136. https://doi.org/https://doi.org/10.1163/138537809X12498721974589

Babaie, S. (2013). Frontiers of Visual Taboo: Painted indecencies in Isfahan. In F. Leoni \& M. Natif (Eds.), Eros and Sexuality in Islamic Art (pp. 131-155). https://doi.org/10.4324/9781315094397-6

Bailey, G. A. (1998). The Indian Conquest of Catholic Art: The Mughals, the Jesuits, and Imperial Mural Painting. Art Journal, 57(1), 24-30. https://doi.org/10.2307/777989

Bailey, G. A. (2001). Art on the Jesuit missions in Asia and Latin America, 1542-1773. Toronto: University of Toronto Press.

Beach, M. C. (2004). Visions of the West in Mughal Art. In J. Flores \& N. V. e Silva (Eds.), Goa and the Great Mughal (pp. 170-189). London: Calouste Gulbenkian Museum \& Scala.

Bhatnagar, P. (2009). Decorative Design History in Indian Textiles and Costumes. Chandigarh: Abhishek Publications.

Brancaforte, E., \& Brentjes, S. (2012). From Rhubarb to Rubies: European Travels to Safavid Iran (1550-1700) The Lands of the Sophi: Iran in Early Modern European Maps (1550-1700). Harvard Library Bulletin, 23(1-2), 1-9. Retrieved from http://www.tandfonline.com/doi/full/10.1080/00210860802246275

Brekka, P. M. (2012). The Antwerp Polyglot Bible (1572): Visual Corpus, New World "Hebrew-Indian" Map, and the Religious Crosscurrents of Imperial Spain. University of Florida.

Camps, A. (2000). Studies in Asian Mission History: 1956 - 1998. Leiden: Brill.

Cipolla, C. M. (1970). European Culture and Overseas Expansions. London: Harmondsworth Penguin.

Cole, J. R. I. (1992). Invisible Occidentalism: Eighteenth-century Indo-Persian Constructions of the West. Iranian Studies, 25(3-4), 3-16. https://doi.org/10.1080/00210869208701776

Crowther, K. J. (1960). Portuguese society in India in the sixteenth and seveteenth centuries. University of Oxford.

Das, A. K. (1978). Mughal painting during Jahangir's time. Calcutta: Asiatic Society.

Digby, S. (1999). Beyond the Ocean: Perception of Overseas in Indo-Persian Sources of the Mughal Period. Studies in History, 15(2), 247-259. https://doi.org/10.1177/025025764309901500203

Edwards, C. C. (1915). Relations of Shah Abbas the Great, of Persia, with the Mogul Emperors , Akbar and Jahangir. Journal of the American Oriental Society, 35, 247-268. 
Fischer-Tiné, H. (2012). "The drinking habits of our countrymen": European Alcohol Consumption and Colonial Power in British India. Journal of Imperial and Commonwealth History, 40(3), 383-408. https://doi.org/10.108o/03086534.2012.712379

Golombek, L., \& Koch, E. (2017). The Mughals, Uzbeks, and the Timurid Legacy. In F. B. Flood \& G. Necipoglu (Eds.), A Companion to Islamic Art and Architecture (pp. 811-845). https://doi.org/10.1002/9781119069218.ch32

Graham, J. (2019). Pepper, Padroado , and Prester John: Portuguese-Thomas Christian Relations and the Creation of an Imperial Patron Saint. In R. Almeida (Ed.), Goa: A Post-Colonial Society Between Cultures (pp. 169-193). Goa.

Guenther, A. (2015). The arrival of European Christians in India during the 16th century. In D. Thomas \& J. A. Chesworth (Eds.), Christian-Muslim Relations. A Bibliographical History. Volume 7 Central and Eastern Europe, Asia, Africa and South America (1500-16oo) (pp. 15-26).

Henn, A. (2014). Hindu-catholic encounters in Goa: Religion, colonialism, and Modernity. In HinduCatholic Encounters in Goa: Religion, Colonialism, and Modernity. Bloomington \& Indiana: Indiana University Press.

Kalus, M. (2015). Foreign Foreigners : Germans in Portuguese India and Beyond in the 16 th Century. XVII Th World Economic History Congress. Kyoto: WEHC.

Koch, E. (2010). The Mughal Emperor As Solomon, Majnun , and Orpheus , or the Album as a Think Tank for Allegory. Muqarnas Online, 27(1), 277-311. https://doi.org/10.1163/22118993_02701012

Koch, E. (2015). Solomonic Angels in a Mughal Sky: The Wall Paintings of the Kala Burj at the Lahore Fort Revisited and Their Reception in Later South Asian and Qajar Art. In N. Gutschow \& K. Weiler (Eds.), Spirits in Transcultural Skies (pp. 151-171). Zurich: Springer International Publishing.

Koch, E. (2019). Being like Jesus and Mary: The Jesuits, the Polyglot Bible and other Antwerp Print Works at the Mughal Court. In K. Margit \& K. Kruger (Eds.), Transcultural Imaginations of The Sacred (pp. 197230). Berlin: Wilhelm Fink Verlag.

Kuczkiewicz-Fras, A. (2011). Akbar the Great (1542-1605) and Christianity. Between Religion and Politics. Orientalia Christiana Cracoviensia, 3, 75-89.

Landau, A. S. (2013). Visibly Foreign, Visibly Female: The Eroticization of Zan-i-Farangi in Seventeenth Century Persian Painting. In F. Leoni \& M. Natif (Eds.), Eros and Sexuality in Islamic Art (pp. 99-130). Burlington: Ashgate Publishing.

Langer, A. (2013). European Influences on Seven- teenth-Century Persian Painting: Of Handsome Europeans, Naked Ladies and Parisian Timepieces. In A. Langer (Ed.), The Fascination of Persia (pp. 170-237). Scheidegger and Spiess.

Lefèvre, C. (2012). The Majālis-i Jahāngīrī (1608-11): Dialogue and Asiatic Otherness at the Mughal Court. Journal of the Economic and Social History of the Orient, 55(2-3), 255-286.

Losty, J. P., \& Roy, M. (2012). Mughal India: art, culture and empire: manuscripts and paintings in the British Library. London: British Library.

Maclagan, E. D. (1932). The Jesuits and Great Mogul. London: Burns, Oates and Washbroune.

Marcocci, G. (2014). Jesuit Missionaries and the Portuguese Inquisition in South Asia: A Controversial History (16th-18th centuries). In A. Amaladass \& I. G. Zupanov (Eds.), Intercultural Encounter and the Jesuit Mission in South Asia (16th -18th Centuries) (First, pp. 232-258). Bangalore: Asian Trading Corporation.

Markel, S. (2015, July 30). The Enigmatic Image: Curious Subjects in Indian Art. Asian Art, pp. 1-21. Retrieved from https://www.asianart.com/articles/enigmatic/index.html 
Moin, A. (2014). Akbar' s “Jesus” and Marlowe's “ Tamburlaine ”: Strange Parallels of Early Modern Sacredness. Fragments, 3, 1-21.

Natif, M. (2018). Mughal Occidentalism: Artistic Encounters between Europe and Asia at the Courts of India 1580-1630 (Hardback). Leiden: Br.

O'Malley, J. W., Bailey, G. A., Harris, S. J., \& Kennedy, T. F. (Eds.). (200o). The Jesuits: Cultures, Sciences and the Arts 1540-1773 (Reprint). London: University of Toronto Press.

Okada, A. (2004). The Representation of Jesuit Missionaries in Mughal Painting. In J. Flores \& N. V. e Silva (Eds.), Goa and the Great Mughal (pp. 190-199). London: Calouste Gulbenkian Museum \& Scala.

Panikkar, K. M. (1953). Asia and Western Dominance. London: George Allen and Unwin.

Parodi, L. E. (2001). Solomon, the Messenger and the Throne Themes from a Mughal Tomb. East and West, 51(1/2), 127-142. Retrieved from http://www.jstor.org/stable/29757497

Pearson, M. N., \& Johnson, G. (1987). The New Cambridge History of India: Portuguese in India. London: Cambridge University Press.

Razvi, M. C. (2012). European Travelers in the Mughal Empire: Jahangir's Court through English Eyes (pp. 113). pp. 1-13. Retrieved from https://www.academia.edu/6o86363/The_Mughal_Empire_through_European_Eyes

Rice, Y. (2009). The Brush and the Burin: Mogul Encounters with European Engravings. In J. Anderson (Ed.), 32nd International Congress of History of Art: Crossing Cultures: Conflict, Migration and Convergences (pp. 305-310). Melbourne: Miegunyah Press.

Rice, Y. (2017). Lines of Perception: European prints and the Mughal kitabkhana. In S. K. Schmidt \& E. H. Wouk (Eds.), Prints in Translation, 1450-750: Image, Materiality, Space (pp. 202-223). London and New York: Routledge.

Rice, Y. (2018). The Global Aspirations of the Mughal Album. In S. Schrader (Ed.), Rembrandt and the Inspiration of India (pp. 61-77). Los Angeles: J Paul Getty Museum.

Rogers, J. M. (1993). Mughal Miniatures. London: British Museum Press.

Salonia, M. (2019). The First Voyage of Giovanni da Empoli to India: Mercantile Culture, Christian Faith, and the Early Production of Knowledge about Portuguese Asia. International Journal of Maritime History, 31(1), 3-18. https://doi.org/10.1177/o843871418822446

Singh, A. K. (1992). Cist Burials in Kinnaur, Western Himalayas : A Preliminary Report on Recent Discovery. Central Asiatic Journal, 43(2), 249-258.

Subrahmanyam, S. (2005). Taking stock of the Franks: South Asian views of Europeans and Europe, 1500180o. The Indian Economic and Social History Review, 42(1), 69-100. https://doi.org/10.1177/001946460504200103

Subrahmanyam, S. (2012). The Portuguese Empire in Asia, 1500-170o: A Political and Economic History. London: John Wiley and Sons.

Subrahmanyam, S. (2017). Europe’s India: Words, People,Empires,150o-18oo. Cambridge: Harvard University Press.

Subrahmanyam, S. (2018). Hybrid affairs: Cultural histories of the East India companies. Indian Economic and Social History Review, 55(3), 419-438. https://doi.org/10.1177/o019464618778408

Subrahmanyam, S. (2019). Morality and Empire: Cases, Norms, and Exceptions in Sixteenth-Century Portuguese Asia. In C. Ginzburg \& L. Biasiori (Eds.), A Historical Approach to Casuistry : Norms and Exceptions in a Comparative Perspective (1st ed., pp. 219-238). London: Bloomsbury Academic. 
Truschke, A. (2016). Deceptive Familiarity: European Perceptions of Access at the Mughal Court. In D. Raeymaekers \& S. Derks (Eds.), The Key to Power? : The Culture of Access in Princely Courts, 1400-1750 (Vol. 8, pp. 65-102). Leiden: Brill.

Vanina, E. (2013). Roads of (Mis)Understanding: European Travellers in India (Fifteenth to Seventeenth Century). Indian Historical Review, 40(2), 267-284. https://doi.org/10.1177/0376983613499678 